\title{
27. DATA REPORT: UPPER CENOZOIC DINOFLAGELLATE CYSTS FROM THE CONTINENTAL SLOPE AND RISE OFF NEW JERSEY ${ }^{1}$
}

\author{
Laurent de Verteuil ${ }^{2}$
}

\section{INTRODUCTION}

This report contains the occurrence data for dinoflagellate cysts recorded from 163 samples taken from Sites 902 through 906, during Ocean Drilling Program (ODP) Leg 150. The dinoflagellate cyst (dinocyst) stratigraphy has been presented in Mountain, Miller, Blum, et al. (1994), and was based on these data. This report provides the full dinocyst data set supporting the dinocyst stratigraphic interpretations made in Mountain, Miller, Blum, et al. (1994). For Miocene shipboard dinocyst stratigraphy, I delineated 10 informal zones: pre$\mathrm{A}$, and $\mathrm{A}$ through $\mathrm{I}$, in ascending stratigraphic order. These zones are defined in Shipboard Scientific Party (1994a), and are based on my studies of Miocene dinocyst stratigraphy in the Maryland and Virginia coastal plain (de Verteuil and Norris, 1991, 1992; de Verteuil, 1995). This zonation has been slightly revised (de Verteuil and Norris, in press, a), and the new formal zone definitions are repeated below. Each new zone has an alpha-numeric abbreviation starting with "DN" (for Dinoflagellate Neogene). The equivalence between the informal zones reported in Mountain, Miller, Blum, et al. (1994), and the new DN zones is illustrated in Figure 1. For clarity, I delineated both zonations in the range charts that accompany this report (Tables 1-6). De Verteuil and Norris (in press, a), using these and other data, correlated the DN zonation with the geological time scale of Berggren et al. (1995). Figure 2 summarizes these correlations and can be used to check the chronostratigraphic position of samples in this report, as determined by dinocyst stratigraphy. A thorough discussion of the basis for, and levels of uncertainty associated with, these correlations to the Cenozoic time scale can be found in de Verteuil and Norris (in press, a).

The Appendix lists all the dinocyst taxa recorded during shipboard analyses of Leg 150 samples. Open nomenclature is used for undescribed taxa. The range charts and Appendix also include reference to several new taxa that de Verteuil and Norris (in press, b) described from Miocene coastal plain strata in Maryland and Virginia. Names of these taxa in Tables 1 through 6 and in the Appendix of this report are not intended for effective publication as defined in the International Code of Botanical Nomenclature (ICBN, Greuter et al., 1994). Therefore, taxonomic nomenclature contained in this report is not to be treated as meeting the conditions of effective and valid publication (ICBN; Article 29).

\section{Miocene Dinocyst Zonation}

(DN1) Chiropteridium galea Interval Zone: Interval from the highest occurrence (HO) of Distatodinium biffii Brinkhuis et al. 1992 to the HO of Chiropteridium galea (Maier) Sarjeant 1983. Upper upper Oligocene to lower lower Miocene.

(DN2) Sumatradinium soucouyantiae Interval Zone: Interval from the HO of Chiropteridium galea (Maier) Sarjeant 1983 to the

'Mountain, G.S., Miller, K.G., Blum, P., Poag, C.W., and Twichell, D.C. (Eds.), 1996. Proc. ODP, Sci. Results, 150: College Station, TX (Ocean Drilling Program).

${ }^{2}$ Department of Geology, Earth Sciences Centre, University of Toronto, 22 Russell St., Toronto, Ontario, Canada M5S 3B1. devert@quartz.geology.utoronto.ca

\begin{tabular}{|c|c|c|c|c|}
\hline \multirow[b]{4}{*}{ 㘝 } & \multirow{3}{*}{$\begin{array}{l}\text { ¿ } \\
\text { 을 }\end{array}$} & I & DN10 & Selenopemphix armageddonensis Interval Zone \\
\hline & & $\mathrm{H}$ & DN9 & Hystrichosphaeropsis obscura Interval Zone \\
\hline & & G & DN8 & Palaeocystodinium golzowense Interval Zone \\
\hline & \multirow{4}{*}{$\frac{\frac{U}{\bar{n}}}{\frac{D}{E}}$} & $\mathrm{~F}$ & DN7 & Cannosphaeropsis passio Range Zone \\
\hline 2 & & E & DN6 & Selenopemphix dionaeacysta Interval Zone \\
\hline \multirow{5}{*}{$\begin{array}{l}\cup \\
0 \\
- \\
\Sigma\end{array}$} & & D & DN5 & Batiacasphaera sphaerica Interval Zone \\
\hline & & $\mathrm{C}$ & DN4 & Distatodinium paradoxum Interval Zone \\
\hline & \multirow{3}{*}{$\begin{array}{l}\text { ఏ } \\
\text { 3. }\end{array}$} & B & DN3 & Cousteaudinium aubryae Interval Zone \\
\hline & & A & DN2 & Sumatradinium soucouyantiae Interval Zone \\
\hline & & & DN1 & Chiropteridium galea Interval Zone \\
\hline
\end{tabular}

Figure 1. Schematic comparison of the informal dinocyst zones reported in the Leg 150 Initial Reports, and the formalized dinocyst zonation of de Verteuil and Norris (in press, a). There is one-to-one equivalence between Zones $\mathrm{C}$ through I and Zones DN4 through DN10, because each pair of zones in the two zonations has the same definition. Zones pre-A through $\mathrm{B}$ and Zones DN1 through DN3 differ as discussed in the text and as illustrated.

$\mathrm{HO}$ of Exochosphaeridium insigne de Verteuil and Norris in press, b. Lower lower Miocene to middle lower Miocene.

(DN3) Cousteaudinium aubryae Interval Zone: Interval from the $\mathrm{HO}$ of Exochosphaeridium insigne de Verteuil and Norris in press, b, to the lowest occurrence (LO) of Labyrinthodinium truncatum Piasecki 1980. Middle lower Miocene to upper lower Miocene.

(DN4) Distatodinium paradoxum Interval Zone: Interval from the LO of Labyrinthodinium truncatum Piasecki 1980 to the HO of Distatodinium paradoxum (Brosius) Eaton 1976. Upper lower Miocene to lower middle Miocene.

(DN5) Batiacasphaera sphaerica Interval Zone: Interval from the $\mathrm{HO}$ of Distatodinium paradoxum (Brosius) Eaton 1976 to the $\mathrm{HO}$ of Systematophora placacantha (Deflandre and Cookson) Davey et al. 1969. Lower middle Miocene to middle middle Miocene.

(DN6) Selenopemphix dionaeacysta Interval Zone: Interval from the HO of Systematophora placacantha (Deflandre and Cookson) Davey et al. 1969 to the LO of Cannosphaeropsis passio de Verteuil and Norris in press, $b$.

(DN7) Cannosphaeropsis passio Range Zone: Interval between the LO and the HO of Cannosphaeropsis passio de Verteuil and Norris in press, b. Middle middle Miocene to upper middle Miocene.

(DN8) Palaeocystodinium golzowense Interval Zone: Interval between the HO of Cannosphaeropsis passio de Verteuil and Norris in press, b, to the HO of Sumatradinium soucouyantiae de Verteuil and Norris 1992. Lower upper Miocene to middle upper Miocene.

(DN9) Hystrichosphaeropsis obscura Interval Zone: Interval from the HO of Sumatradinium soucouyantiae de Verteuil and Norris 
Table 1. Stratigraphic distribution of dinocyst taxa from Holes 902A, 902C, and 902D, in ascending highest occurrence.

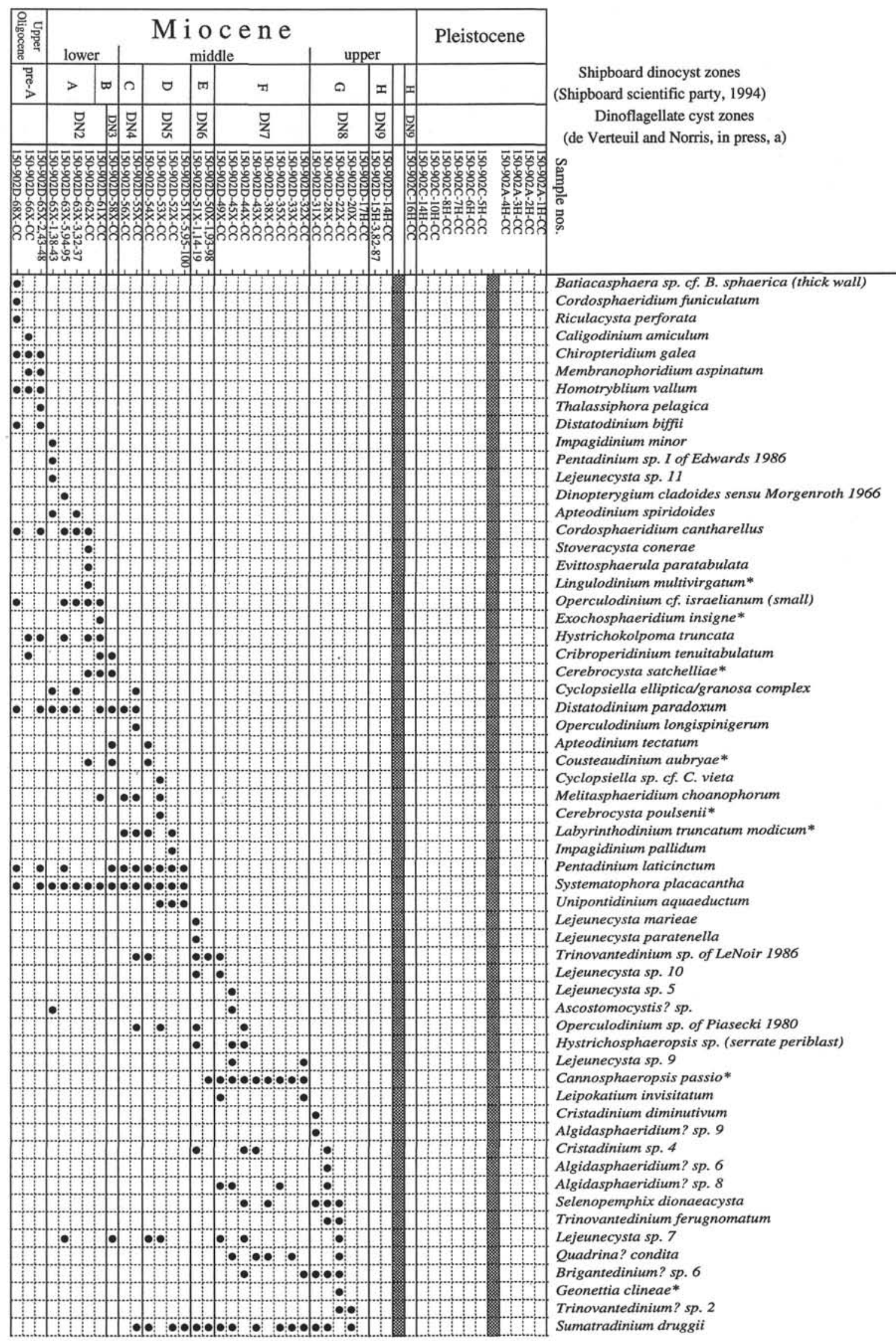


Table 1 (continued).

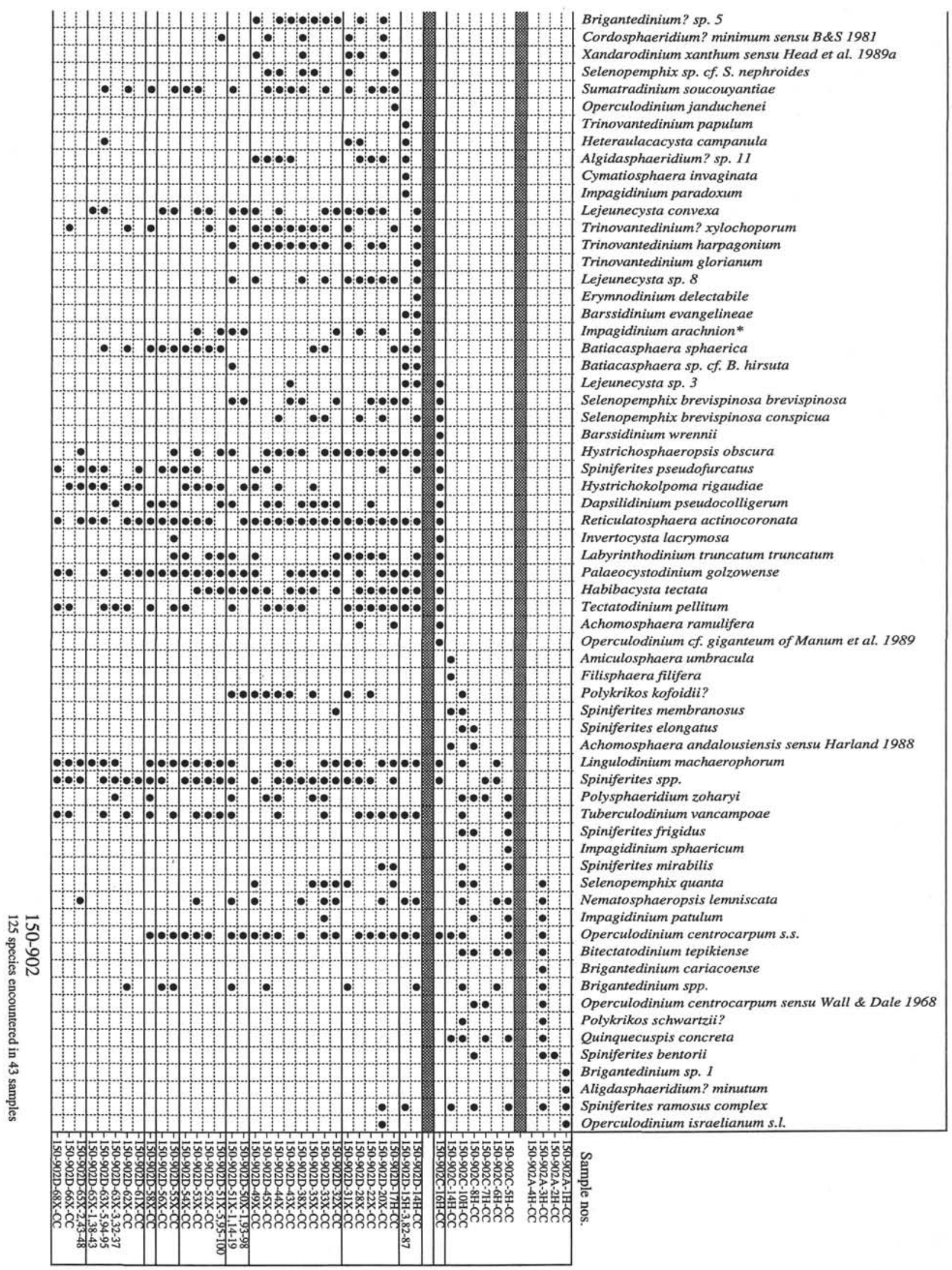

Notes: The shaded rows serve to separate samples from the three holes. The depth (mbsf) for each sample is given in Shipboard Scientific Party (1994b, table 6). Solid dots indicate in situ occurrences. There may be some stratigraphic overlap between Samples 150-902C-16H-CC and 150-902D-14H-CC. Taxon names followed by an asterisk (*) are from de Verteuil and Norris (in press, b, c); published taxon names followed by a question mark (?) indicate that assignment to the taxon is tentative. 
Table 2. Stratigraphic distribution of dinocyst taxa from Hole 903A, in ascending highest occurrence.

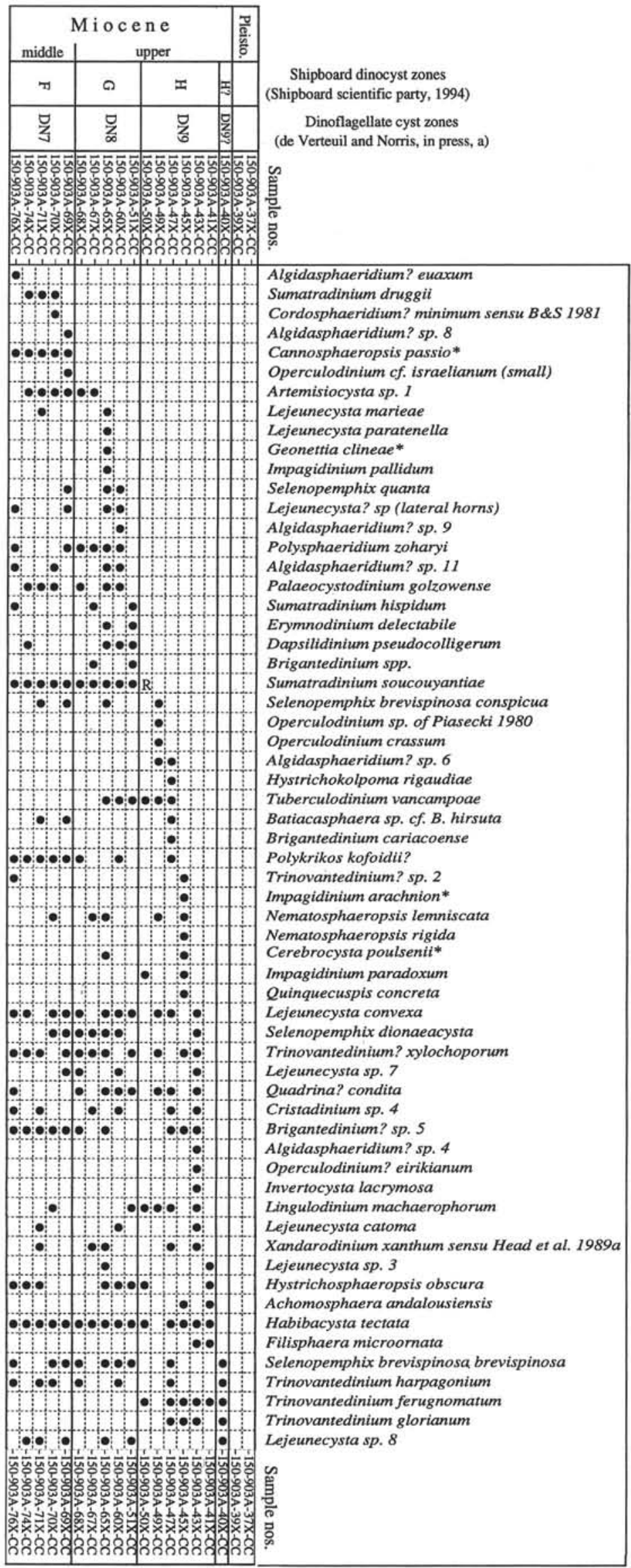


Table 2 (continued).

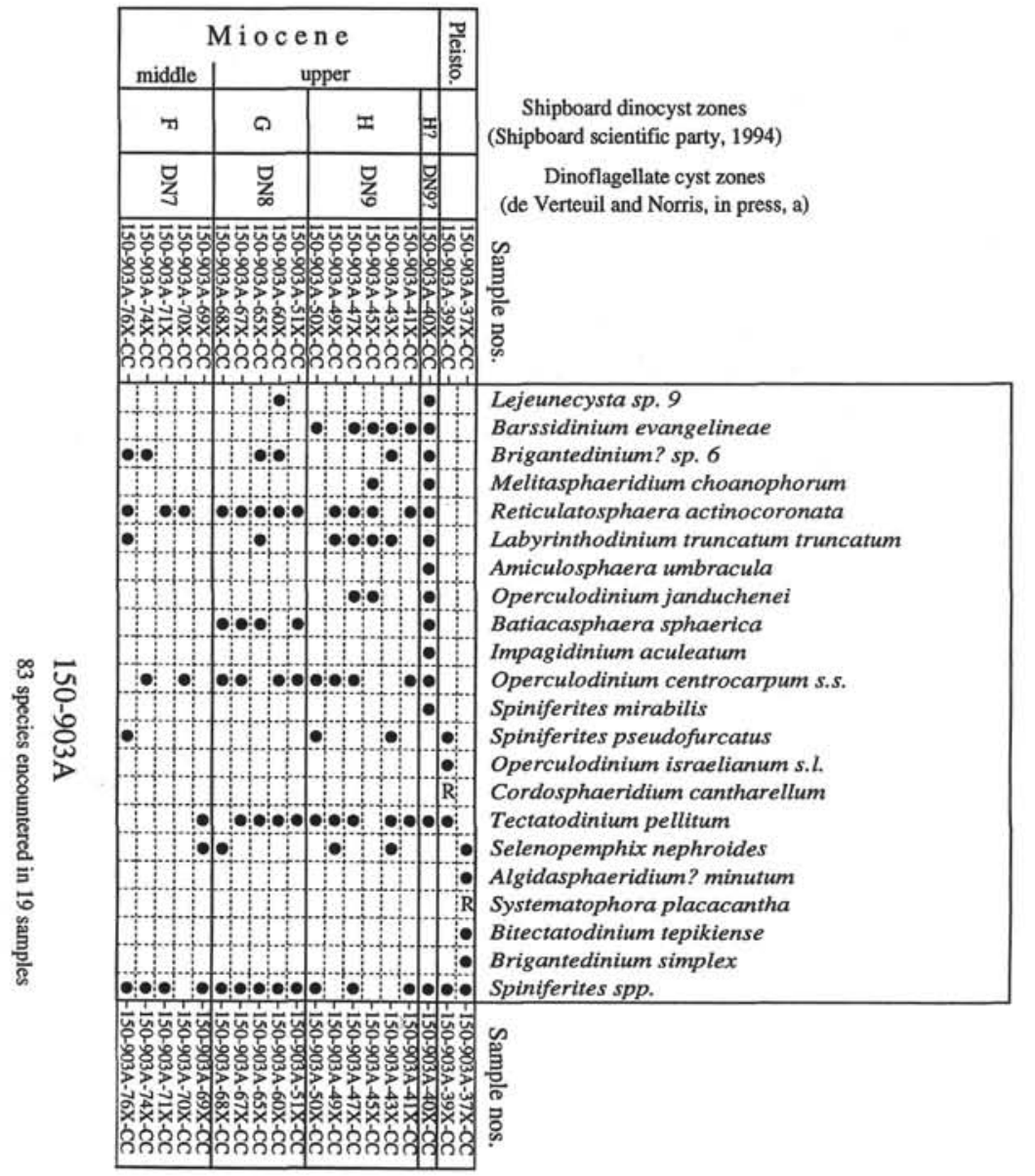

Notes: The depth (mbsf) for each sample is given in Shipboard Scientific Party (1994c, table 4). Solid dots indicate in situ occurrences; the symbol "R" indicates occurrences that are considered to have resulted from reworking. Taxon names followed by an asterisk $\left(^{*}\right)$ are from de Verteuil and Norris (in press, b, c); published taxon names followed by a question mark (?) indicate that assignment to the taxon is tentative.

1992 to the HO of Hystrichosphaeropsis obscura Habib 1972. Middle upper Miocene to upper upper Miocene.

(DN10) Selenopemphix armageddonensis Interval Zone: Interval from the $\mathrm{HO}$ of Hystrichosphaeropsis obscura Habib 1972 to the HO of Erymnodinium delectabile (de Verteuil and Norris) Lentin et al. 1994. Upper upper Miocene.

\section{Zonation Changes}

Comparing the definitions of the informal dinocyst zones (Shipboard Scientific Party, 1994a) with those given above shows that the informal Zones $\mathrm{C}$ through I are precisely equivalent to the new formal Zones DN4 through DN10 (Fig. 1). (The informal taxon Cannosphaeropsis sp. cf. C. utinensis refers to the species Cannosphaeropsis passio de Verteuil and Norris in press, b). The only changes occur between the lower Miocene zones pre-A, A, B and DN1, DN2, DN3.

Informal dinocyst Zone pre-A was defined as the interval from the HO of Saturnodinium (al Thalassiphora?) pansum (Stover) Brinkhuis et al. 1992, to the HO of Chiropteridium spp. (Shipboard Scientific Party, 1994a). In the lower Miocene of the New Jersey continental margin, the $\mathrm{HO}$ of Chiropteridium spp. and the $\mathrm{HO}$ of Chiropteridium galea are the same biostratigraphic event. This is based on acceptance of the taxonomic synonymies listed for $C$. galea in Lentin and Williams (1993). The HO of S. pansum near the middle of calcareous nannofossil Zone NP25, however, is below the HO of Dis- tatodinium biffii, which is in the upper part of Zone NP25 (Brinkhuis et al., 1992). Thus, the lower boundary of Zone pre-A is below that of Zone DN1, but the upper boundaries of both zones are the same (Fig. 1).

The upper boundaries of Zone B and Zone DN3 are both defined on the LO of Labyrinthodinium truncatum Piasecki 1980, so that together, Zones A and B and Zones DN2 and DN3, both span the same chronostratigraphic interval (Fig. 1). The HO of Cordosphaeridium cantharellum (Brosius) Gocht 1969, which defines the boundary between Zones A and B, is below the $\mathrm{HO}$ of Exochosphaeridium insigne de Verteuil and Norris (in press, b), which defines the boundary between Zones DN2 and LN3 (Fig. 1).

\section{CONCLUSIONS}

The range data for Neogene dinoflagellate cysts presented in Tables 1 through 6 demonstrate the utility of this group for stratigraphic subdivision in the western North Atlantic. Integration of these data with results from sedimentological, isotopic, paleontological and geophysical studies, in a sequence stratigraphic framework, is under way. The distribution of dinocyst taxa in Leg 150 sites is consistent with that observed by de Verteuil and Norris (in press, a) for the adjacent Atlantic coastal plain. For many taxa, such as those included in Figure 2, these ranges appear to approximately reflect the known 
Table 3. Stratigraphic distribution of dinocyst taxa from Hole 903C, in ascending highest occurrence.

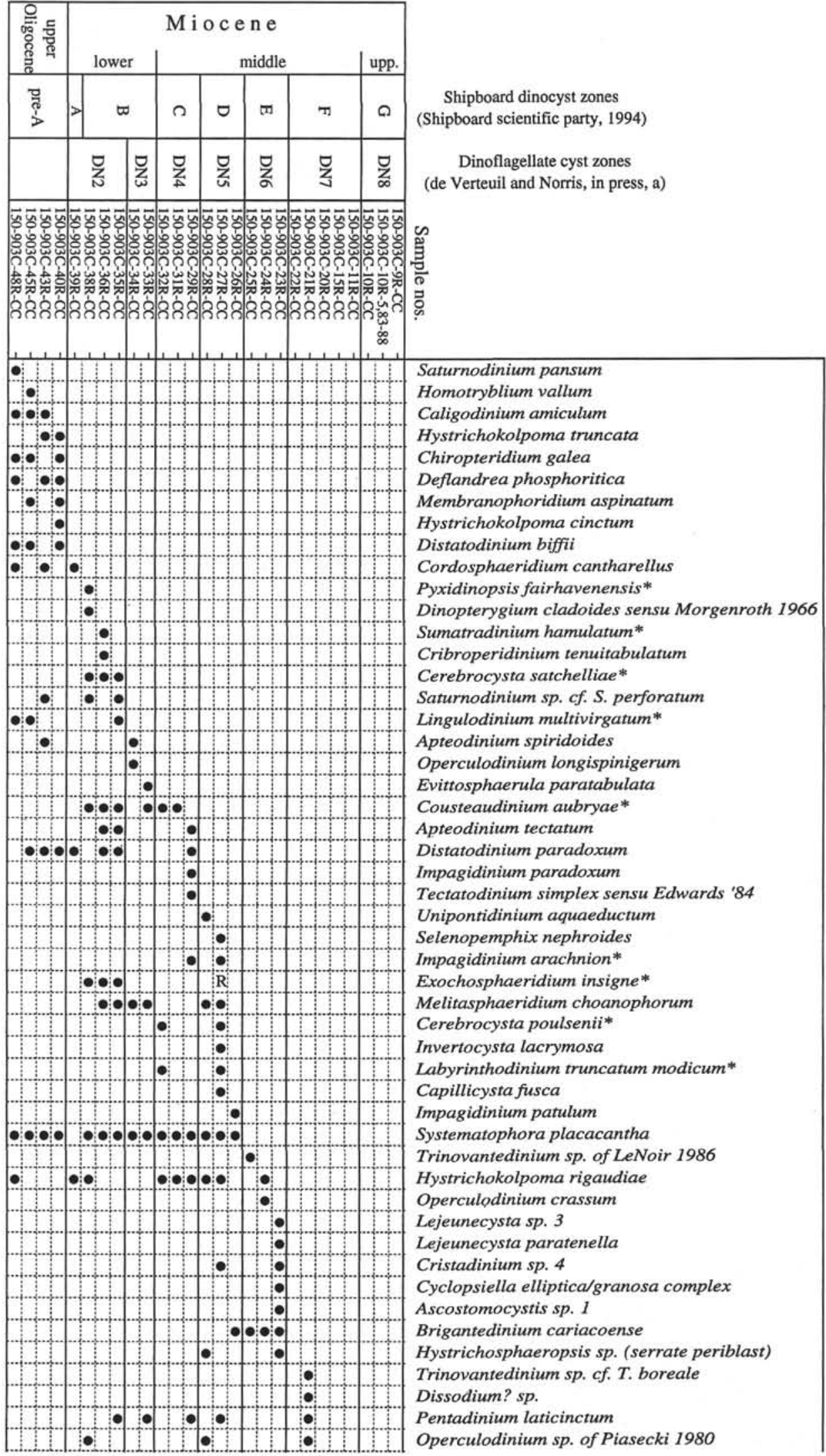


Table 3 (continued).

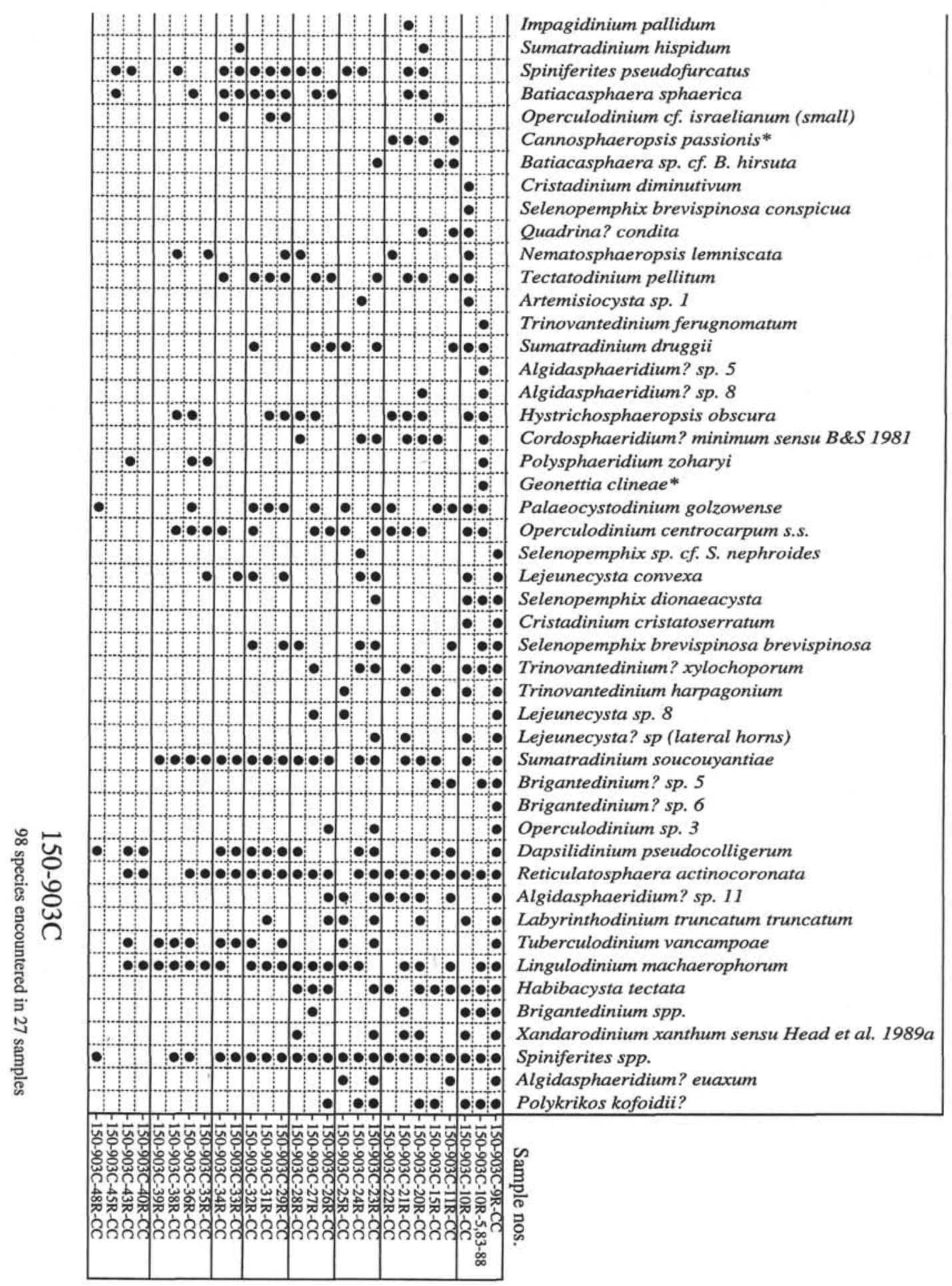

Notes: The depth (mbsf) for each sample is given in Shipboard Scientific Party (1994c, table 4). Solid dots indicate in situ occurrences; the symbol "R" indicates occurrences that are considered to have resulted from reworking. Taxon names followed by an asterisk (*) are from de Verteuil and Norris (in press, b, c); published taxon names followed by a question mark (?) indicate that assignment to the taxon is tentative. 
Table 4. Stratigraphic distribution of dinocyst taxa from Hole 904A, in ascending highest occurrence.

\begin{tabular}{|c|c|c|c|c|}
\hline \multicolumn{4}{|c|}{ Miocene } & \multirow{4}{*}{ 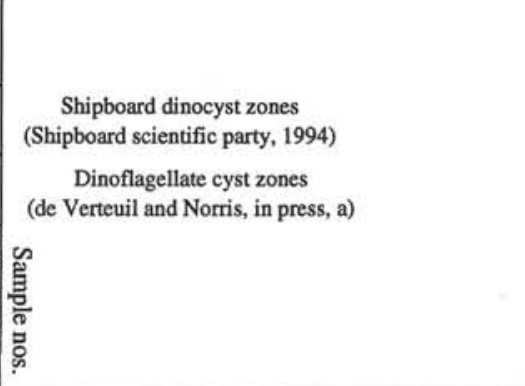 } \\
\hline$>0$ & & נדי & ه & \\
\hline 放 & & $\underset{\xi}{Z}$ & $\underset{\infty}{\square}$ & \\
\hline \multicolumn{4}{|c|}{ 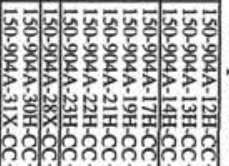 } & \\
\hline :-1. & & & & Cyclopsiella elliptica/granosa complex \\
\hline$\because$ & & & & Apteodinium spiridoides \\
\hline$\bullet$ & & & & Operculodinium placitum \\
\hline - : & & & & Cordosphaeridium cantharellus \\
\hline$\because \bullet$ & & & & Hystrichokolpoma truncata \\
\hline ०० & & & & Lingulodinium multivirgatum* \\
\hline & & & & Trinovantedinium ferugnomatum \\
\hline & i. & & & Lejeunecysta sp. 7 \\
\hline 1. & & & & Spiniferites ramosus complex \\
\hline 0 & & & & Cribroperidinium tenuitabulatum \\
\hline 0 & & & & Operculodinium cf. israelianum (small) \\
\hline 18 & o. & & & Melitasphaeridium choanophorum \\
\hline$\because 0$ & & & & Systematophora placacantha \\
\hline & t. & & & Cousteaudinium aubryae* \\
\hline 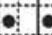 & i. & & & Distatodinium paradoxum \\
\hline & (1) & & & Labyrinthodinium truncatum modicum* \\
\hline & of & & & Spiniferites membranosus \\
\hline & 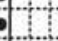 & & & Tectatodinium sp. 3 of Manum et al. 1989 \\
\hline & 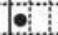 & & & Trinovantedinium sp. of LeNoir 1986 \\
\hline & 6 & & & Apteodinium tectatum \\
\hline$\because 0$ & 0 & & & Pentadinium laticinctum \\
\hline & 0 & & & Tectatodinium simplex sensu Edwards' 84 \\
\hline & 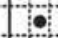 & & & Lejeunecysta sp. 10 \\
\hline & 0 & & & Algidasphaeridium?sp. 4 \\
\hline & : & & & Algidasphaeridium? sp. 10 \\
\hline & & - & & Quadrina? condita \\
\hline & $\bullet$ & $\because$ & & Trinovantedinium? xylochoporum \\
\hline & & $\bullet$ & & Lejeunecysta paratenella \\
\hline & & $\bullet$ & & Nematosphaeropsis rigida \\
\hline & & 0 & & Cordosphaeridium? minimum sensu B\&S 1981 \\
\hline .0 & & $\because$ & & Polysphaeridium zoharyi \\
\hline 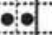 & 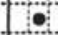 & 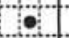 & & Hystrichokolpoma rigaudiae \\
\hline & & $\because 0$ & & Selenopemphix sp. cf. S. nephroides \\
\hline & 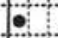 & 10 & & Algidasphaeridium? sp. 8 \\
\hline & $\because$ & $0 \circ$ & & Cannosphaeropsis passio* \\
\hline & & $\bullet$ & & Algidasphaeridium? sp. 11 \\
\hline & e. & 00 & & Labyrinthodinium truncatum truncatum \\
\hline & & 0 & & Polykrikos schwartzii? \\
\hline & & & :- & Selenopemphix quanta \\
\hline & & & -: & Ascostomocystis? sp. \\
\hline & & & - & Nematosphaeropsis lativittatus \\
\hline & & & 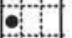 & Operculodinium janduchenei \\
\hline & & & -. & Batiacasphaera sp. cf. B. hirsuta \\
\hline & $0: 0$ & & -1 & Spiniferites spp. \\
\hline & & 6. & : & Lejeunecysta sp. 3 \\
\hline & 0 & & $\bullet$ & Trinovantedinium harpagonium \\
\hline & & $\circ:$ & 0 & Sumatradinium druggii \\
\hline & & 0 & 0. & Brigantedinium? sp. 5 \\
\hline & & - & :- & Brigantedinium? sp. 6 \\
\hline & & & :- & Impagidinium patulum \\
\hline & & & $\circ$ & Heteraulacacysta campanula \\
\hline 9 & 0 & 0 & 0 & Operculodinium centrocarpum s.s. \\
\hline & 0 & & $\circ$ & Impagidinium paradoxum \\
\hline & & & $\because$ & Algidasphaeridium? euaxum \\
\hline & - & o: & 0 & Lejeunecysta convexa \\
\hline & & & $\circ:$ & Selenopemphix dionaeacysta \\
\hline & e: & (:). & 0.0 & Selenopemphix brevispinosa brevispinosa \\
\hline & 0 & 0 & 0 & Lejeunecysta sp. 8 \\
\hline 0 & 0.9 & 0.0 & 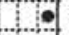 & Sumatradinitum soucouyantiae \\
\hline & é: & 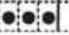 & $\bullet$ & Hystrichosphaeropsis obscura \\
\hline
\end{tabular}


Table 4 (continued).

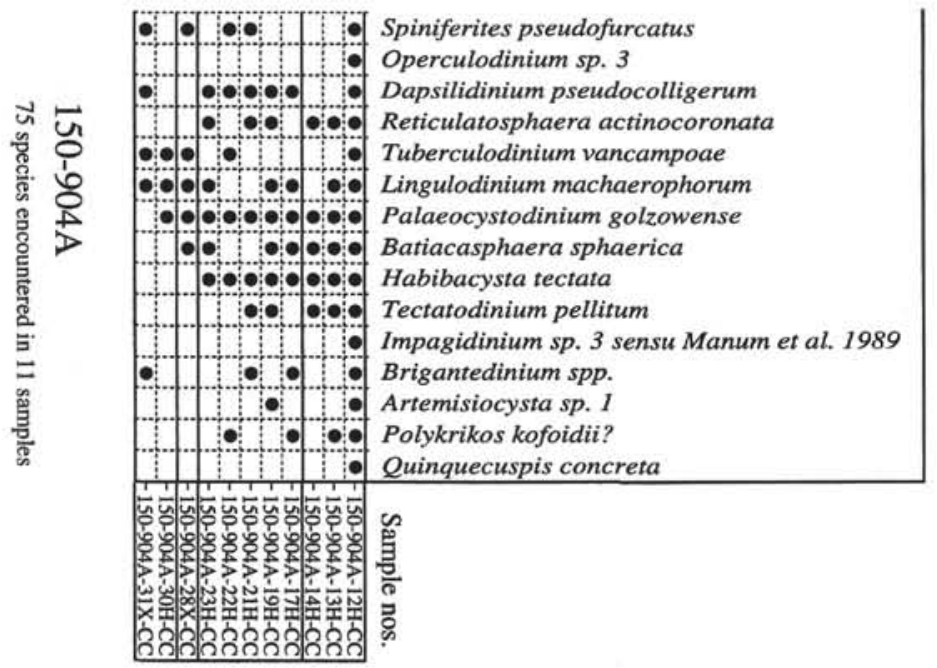

Notes: The depth (mbsf) for each sample is given in Shipboard Scientific Party (1994d, table 5). Solid dots indicate in situ occurrences. Taxon names followed by an asterisk $(*)$ are from de Verteuil and Norris (in press, b, c); published taxon names followed by a question mark (?) indicate that assignment to the taxon is tentative.

maximum stratigraphic ranges globally. For others, including many of the protoperidinioid species, far less is known regarding their distribution in time and space.

The prevalence of open nomenclature in the taxon list (Appendix) indicates the substantial number of undescribed species present in these Neogene assemblages. This is particularly so among forms with probable protoperidinioid affinity (e.g., Algidasphaeridium? spp. and Brigantedinium? spp.).

\section{REFERENCES}

Anstey, C.E., 1992. Biostratigraphic and paleoenvironmental interpretation of upper middle Miocene through lower Pleistocene dinoflagellate cyst, acritarch and other algal palynomorph assemblages from Ocean Drilling Program Leg 105, Site 645, Baffin Bay [M.Sci. dissert.]. Univ. of Toronto, Toronto.

Berggren, W.A., Kent, D.V., Swisher, C.C., III, and Aubry, M.-P., 1995. A revised Paleogene geochronology and chronostratigraphy. In Berggren, W.A., Kent, D.V., Aubry, M.P., and Hardenbol, J. (Eds.), Geochronology, Time Scales and Global Stratigraphic Correlation: Spec. Publ. Soc. Econ. Paleontol. Mineral., 54:129-212.

Brinkhuis, H., Powell, A.J., and Zevenboom, D., 1992. High-resolution dinoflagellate cyst stratigraphy of the Oligocene/Miocene transition interval in north-west and central Italy. In Head, M.J., and Wrenn, J.H. (Eds.), Neogene and Quaternary Dinoflagellate Cysts and Acritarchs. Am. Assoc. Stratigr. Palynol. Found., 219-258.

deVernal, A., and Mudie, P.J., 1989. Pliocene and Pleistocene palynostratigraphy at ODP Sites 646 and 647, eastern and southern Labrador Sea. In Srivastava, S.P., Arthur, M.A., Clement, B., et al., Proc. ODP, Sci. Results, 105: College Station, TX (Ocean Drilling Program), 401-422.

de Verteuil, L., 1995. Miocene dinoflagellate cyst taxonomy and biostratigraphy of the Chesapeake Group, Salisbury Embayment, U.S.A. [Ph.D. dissert.]. Univ. of Toronto, Toronto.

de Verteuil, L., and Norris, G., 1991. Neogene dinoflagellate cyst biostratigraphy of the Salisbury Embayment. Geol. Soc. Am. Abstr. Prog., 23:144.

, 1992. Miocene Protoperidiniacean dinoflagellate cysts from the Maryland and Virginia coastal plain. In Head, M.J., and Wrenn, J.H. (Eds.), Neogene and Quaternary Dinoflagellate Cysts and Acritarchs. Am. Assoc. Stratigr. Palynol. Found., 391-430.

, in press a. Part I: Dinoflagellate cyst zonation and allostratigraphy of the Chesapeake Group. In de Verteuil, L., and Norris, G., Miocen Dinoflagellate Stratigraphy and Systematics of Maryland and Virginia. Micropaleontology, Vol. 42, Suppl.
, in press b. Part II: Homology and structure in dinoflagellate cyst terminology. In de Verteuil, L., and Norris, G., Miocene Dinoflagellate Stratigraphy and Systematics of Maryland and Virginia. Micropaleontology, Vol. 42, Suppl.

, in press c. Upper Miocene Geonettia clineae gen. et sp. nov., an opportunistic coastal embayment dinoflagellate of the Homotryblium Complex. Micropaleontology.

Edwards, L.E., 1984. Miocene dinocysts from Deep Sea Drilling Project Leg 81, Rockall Plateau, Eastern North Atlantic Ocean. In Roberts, D.G., Schnitker, D., et al., Init. Repts. DSDP, 81: Washington (U.S. Govt. Printing Office), 581-594.

1986. Late Cenozoic dinoflagellate cysts from South Carolina, U.S.A. In Wrenn, J.H., Duffield, S.L., and Stein, J.A. (Eds.), Papers from the First Symposium on Neogene Dinoflagellate Cyst Biostratigraphy. Am. Assoc. Stratigr. Palynol. Contrib. Ser., 17:47-57.

Greuter, W., Barrie, F.R., Burdet, H.M., Chaloner, W.G., Demoulin, V., Hawksworth, D.L., Jørgensen, P.M., Nicolson, D.H., Silvia, P.C., Trehane, P., and McNeill, J. (Eds.), 1994. International Code of Botanical Nomenclature (Tokyo Code): Königstein (Koelts Scientific Books).

Harland, R., 1988. Quaternary dinoflagellate cyst biostratigraphy of the North Sea. Palaeontology, 31:877-903.

Head, M.J., 1996. Modern dinoflagellate cysts and their biological affinities. In Jansonius, J., and McGregor, D.C. (Eds.), Palynology: Principles and Applications. Am. Assoc. Stratigr. Palynol. Found., 3:1197-1248.

Lentin, J.K., Fensome, R.A., and Williams, G.L., 1994. The stratigraphic importance of species of Sumatradinium, Barssidinium and Erymnodinium, Neogene dinoflagellate genera from offshore eastern Canada. Can. J. Earth Sci., 31:567-582.

Lentin, J.K., and Williams, G.L., 1993. Fossil Dinoflagellates: Index to Genera and Species, 1993 Edition. Am. Assoc. Stratigr. Palynol. Contrib. Ser., 28

Manum, S.B., Boulter, M.C., Gunnarsdottir, H., Rangnes, K., and Scholze, A., 1989. Eocene to Miocene palynology of the Norwegian Sea (ODP Leg 104). In Eldholm, O., Thiede, J., Taylor, E., et al., Proc. ODP, Sci. Results, 104: College Station, TX (Ocean Drilling Program), 611-662.

Morgenroth, P., 1966. Mikrofossilien und Konkretionen des nordwesteuropäischen Untereozäns. Palaeontogr. Abt. B, 119:1-53.

Mountain, G.S., Miller, K.G., Blum, P., et al., 1994. Proc. ODP, Init. Repts., 150: College Station, TX (Ocean Drilling Program).

Piasecki, S., 1980. Dinoflagellate cyst stratigraphy of the Miocene Hodde and Gram Formations, Denmark. Bull. Geol. Soc. Den., 29:53-76.

Shipboard Scientific Party, 1994a. Explanatory notes. In Mountain, G.S., Miller, K.G., Blum, P., et al., Proc. ODP, Init. Repts., 150: College Station, TX (Ocean Drilling Program), 21-42. 
, 1994b. Site 902. In Mountain, G.S., Miller, K.G., Blum, P., et al., Proc. ODP, Init. Repts., 150: College Station, TX (Ocean Drilling Program), 63-127.

, 1994c. Site 903. In Mountain, G.S., Miller, K.G., Blum, P., et al., Proc. ODP, Init. Repts., 150: College Station, TX (Ocean Drilling Program), 129-205,

, 1994d. Site 904. In Mountain, G.S., Miller, K.G., Blum, P., et al., Proc. ODP, Init. Repts., 150: College Station, TX (Ocean Drilling Program), 207-253.

, 1994e. Site 905. In Mountain, G.S., Miller, K.G., Blum, P., et al., Proc. ODP, Init. Repts., 150: College Station, TX (Ocean Drilling Program), 255-308.

, 1994f. Site 906. In Mountain, G.S., Miller, K.G., Blum, P., et al., Proc. ODP, Init. Repts., 150: College Station, TX (Ocean Drilling Program), 309-357.

Wall, D., and Dale, B., 1966. "Living fossils" in western Atlantic plankton. Nature, 211:1025-1026.

Date of initial receipt: 1 March 1995

Date of acceptance: 26 September 1995

Ms 150SR-007

\section{APPENDIX}

Dinoflagellate Cyst Taxa

Following is a list of all dinoflagellate cyst taxa recovered from the upper Cenozoic sections at Sites 902 through 906, ODP Leg 150. Published species names followed by a question mark (?) indicate that assignment of material to that species is tentative. Taxonomic references not included in the bibliography are in Lentin and Williams (1993) and Head (1996).

Achomosphaera andalousiensis Jan du Chene 1977

Achomosphaera andalousiensis sensu Harland 1988

Achomosphaera ramulifera (Deflandre) Evitt 1963

Achomosphaera sp. cf. A. ramulifera of Anstey 1992

Algidasphaeridium? euaxum Head 1993

Algidasphaeridium? minutum (Harland and Reid) Matsuoka and Bujak 1988

Algidasphaeridium? sp. 1

Algidasphaeridium? sp. 2

Algidasphaeridium? sp. 3

Algidasphaeridium? sp. 4

Algidasphaeridium? sp. 5

Algidasphaeridium? sp. 6

Algidasphaeridium? sp. 7

Algidasphaeridium? sp. 8

Algidasphaeridium? sp. 9

Algidasphaeridium? sp. 10

Algidasphaeridium? sp. 11

Amiculosphaera umbracula Harland 1979

Apteodinium spiridoides Benedek 1972

Apteodinium tectatum Piasecki 1980

Artemisiocysta sp. 1

Ascostomocystis sp. 1

Ascostomocystis? sp.

Barssidinium evangelineae Lentin et al. 1994

Barssidinium graminosum Lentin et al. 1994

Barssidinium sp. 3

Barssidinium sp. cf. B. graminosum Lentin et al. 1994

Barssidinium wrennii Lentin et al. 1994

Batiacasphaera gemmata Head et al. 1989

Batiacasphaera sphaerica Stover 1977

Batiacasphaera sp. cf. B. hirsuta Stover 1977

Batiacasphaera sp. cf. B. sphaerica (thick wall)

Bitectatodinium tepikiense Wilson 1973

Bitectatodinium? sp. 1

Brigantedinium cariacoense (Wall) Reid 1977

Brigantedinium simplex (Wall) Reid 1977

Brigantedinium spp.

Brigantedinium? sp. 1

Brigantedinium? sp. 2

Brigantedinium? sp. 5
Brigantedinium? sp. 6

Caligodinium amiculum Drugg 1970

Cannosphaeropsis passio de Verteuil and Norris in press b

Capillicysta fusca Matsuoka and Bujak 1987

Cerebrocysta mediterranea Biffi and Manum 1988

Cerebrocysta poulsenii de Verteuil and Norris in press b

Cerebrocysta satchelliae de Verteuil and Norris in press b

Chiropteridium galea (Maier) Sarjeant 1983

Cordosphaeridium cantharellus (Brosius) Gocht 1969

Cordosphaeridium funiculatum Morgenroth 1966

Cordosphaeridium minimum sensu Eaton 1976

Cordosphaeridium? minimum sensu Benedek and Sarjeant 1980

Cousteaudinium aubryae de Verteuil and Norris in press b

Cribroperidinium tenuitabulatum (Gerlach) Helenes 1984

Cristadinium cristatoserratum Head et al. 1989

Cristadinium diminutivum Head et al. 1989

Cristadinium sp. 4

Cyclopsiella granosa Matsuoka 1983

Cyclopsiella sp. cf. C. vieta Drugg and Loeblich 1967

Cyclopsiella? sp. cf. C? trematophora (Cookson and Eisenack) Lentin and Williams 1977

Cymatiosphaera invaginata $\mathrm{Head}$ et al. 1989

Cyst type I of de Vernal and Mudie 1989

Danea sp. of Edwards 1984

Dapsilidinium pseudocolligerum (Stover) Bujak et al. 1980

Deflandrea phosphoritica Eisenack 1938

Dinopterygium cladoides sensu Morgenroth 1966

Dissodium? sp.

Distatodinium biffii Brinkhuis, Powell and Zavenboom 1992

Distatodinium ellipticum (Cookson) Eaton 1976

Distatodinium paradoxum (Brosius) Eaton 1976

Erymnodinium delectabile (de Verteuil and Norris) Lentin et al. 1994

Evittosphaerula paratabulata Manum 1979

Exochosphaeridium insigne de Verteuil and Norris in press b

Filisphaera filifera Bujak 1984

Filisphaera microornata (Head et al.) Head 1994

Geonettia clineae de Verteuil and Norris in press c

Habibacysta tectata $\mathrm{Head}$ et al. 1989

Heteraulacacysta campanula Drugg and Loeblich 1967

Homotryblium vallum Stover 1977

Hystrichokolpoma cinctum Klumpp 1953

Hystrichokolpoma rigaudiae Deflandre and Cookson 1955

Hystrichokolpoma truncata Biffi and Manum 1988

Hystrichosphaeropsis obscura Habib 1972

Hystrichosphaeropsis sp. (serrate periblast)

Impagidinium aculeatum (Wall) Lentin and Williams 1981

Impagidinium arachnion de Verteuil and Norris in press b

Impagidinium fenestroseptatum Head et al. 1989

Impagidinium japonicum Matsuoka 1983

Impagidinium minor Biffi and Manum 1988

Impagidinium multiplexum Wall and Dale 1968

Impagidinium pallidum Bujak 1984

Impagidinium paradoxum (Wall) Stover and Evitt 1978

Impagidinium patulum (Wall) Stover and Evitt 1978

Impagidinium sp. 3

Impagidinium sp. 3 of Manum et al. 1989

Impagidinium sphaericum (Wall) Lentin and Williams 1981

Impagidinium velorum Bujak 1984

Incertae sedis sp. I of Edwards 1984

Invertocysta lacrymosa Edwards 1984

Labyrinthodinium truncatum ssp. modicum de Verteuil and Norris in press b

Labyrinthodinium truncatum ssp. truncatum Piasecki 1980

Leipokatium invisitatum Bradford 1975

Lejeunecysta catoma Harland 1991

Lejeunecysta communis Biffi and Grignani 1983

Lejeunecysta convexa Matsuoka and Bujak 1988

Lejeunecysta marieae Harland et al. 1991

Lejeunecysta paratenella (Benedek) Artzner and Dorhofer 1978

Lejeunecysta sp. 3

Lejeunecysta sp. 5

Lejeunecysta sp. 7

Lejeunecysta sp. 8

Lejeunecysta sp. 9

Lejeunecysta sp. 10 
Lejeunecysta sp. 11

Lejeunecysta? sp. (lateral horns)

Lingulodinium machaeophorum (Deflandre and Cookson) Wall 1967

Lingulodinium multivirgatum de Verteuil and Norris in press b

Melitasphaeridium choanophorum (Deflandre and Cookson) Harland and Hill 1979

Membranophoridium aspinatum Gerlach 1961

Nematosphaeropsis lativittatus Wrenn 1988

Nematosphaeropsis lemniscata Bujak 1984

Nematosphaeropsis rigida Wrenn 1988

Operculodinium centrocarpum s.s. (Deflandre and Cookson) Wall 1967

Operculodinium centrocarpum sensu Wall and Dale 1966

Operculodinium cf. giganteum of Manum et al. 1989

Operculodinium crassum Harland 1979

Operculodinium israelianum s.l. (Rossignol) Wall 1976

Operculodinium sp. cf. O. israelianum (Rossignol) Wall 1967

Operculodinium janduchenei Head et al. 1989

Operculodinium longispinigerum Matsuoka 1983

Operculodinium placitum Drugg and Loeblich 1967

Operculodinium sp. 3 of de Verteuil and Norris in press, b

Operculodinium sp. of Piasecki 1980

Operculodinium? eirikianum Head et al. 1989

Palaeocystodinium golzowense Alberti 1961

Pentadinium laticinctum Gerlach 1961

Pentadinium sp. I of Edwards 1986

Polykrikos kofoidii? Chatton 1914

Polykrikos schwartzii? Butschli 1873

Polysphaeridium zoharyi (Rossignol) Bujak et al. 1980

Protoperidinium subinerme (Paulsen) Loeblich III 1969

Pyxidinopsis fairhavenensis de Verteuil and Norris in press b

Pyxidinopsis pastilliformis Matsuoka and Head 1992

Pyxidinopsis sp. 1 of Manum et al. 1989

Quadrina? condita de Verteuil and Norris 1992

Quinquecuspis concreta (Reid) Head 1993

Reticulatosphaera actinocoronata (Benedek) Bujak and Matsuoka 1986

Riculacysta perforata Stover 1977

Saturnodinium (al Thalassiphora?) pansum (Stover) Brinkhuis et al. 1992

Saturnodinium sp. cf. S. perforatum Brinkhuis et al. 1992

Selenopemphix armageddonensis de Verteuil and Norris 1992

Selenopemphix brevispinosa ssp. brevispinosa Head et al. 1989
Selenopemphix brevispinosa ssp. conspicua de Verteuil and Norris 1992 Selenopemphix dionaeacysta Head et al. 1989

Selenopemphix nephroides Benedek 1972

Selenopemphix quanta (Bradford) Matsuoka 1985

Selenopemphix sp. cf. S. armata Bujak 1980

Selenopemphix sp. cf. S. nephroides

Spiniferites bentorii (Rossignol) Wall and Dale 1970

Spiniferites delicatus Reid 1974

Spiniferites elongatus Reid 1974

Spiniferites frigidus Harland 1980

Spiniferites lazus sensu Harland 1988

Spiniferites membranosus (Rossignol) Sarjeant 1970

Spiniferites mirabilis (Rossignol) Sarjeant 1970

Spiniferites pseudofurcatus (Klumpp) Sarjeant 1970

Spiniferites ramosus complex

Spiniferites solidago de Verteuil and Norris in press b

Spiniferites sp. cf. S. rubinus (Rossignol) Sarjeant 1970

Spiniferites spp.

Stoveracysta conerae Biffi and Manum 1988

Sumatradinium druggii Lentin et al. 1994

Sumatradinium hamulatum de Verteuil and Norris in press b

Sumatradinium hispidum (Drugg) Lentin and Williams 1976

Sumatradinium soucouyantiae de Verteuil and Norris 1992

Systematophora placacantha (Deflandre and Cookson) Davey et al. 1969

Tectatodinium pellitum Wall 1967

Tectatodinium simplex of Edwards 1984

Tectatodinium sp. 3 of Manum et al. 1989

Thalassiphora pelagica (Eisenack) Eisenack and Gocht 1960

Trinovantedinium ferugnomatum de Verteuil and Norris 1992

Trinovantedinium glorianum (Head et al.) de Verteuil and Norris 1992

Trinovantedinium harpagonium de Verteuil and Norris 1992

Trinovantedinium papulum de Verteuil and Norris 1992

Trinovantedinium sp. cf. T. boreale Bujak 1984

Trinovantedinium sp. of LeNoir 1986

Trinovantedinium? xylochoporum de Verteuil and Norris 1992

Trinovantedinium? sp. 2

Tuberculodinium vancampoae (Rossignol) Wall 1967

Unipontidinium aquaeductum (Piasecki) Wrenn 1988

Unipontidinium? sp. cf. U. aquaeductum (Piasecki) Wrenn 1988

Xandarodinium xanthum sensu Head et al. 1989 
Table 5. Stratigraphic distribution of dinocyst taxa from Hole 905A, in ascending highest occurrence.

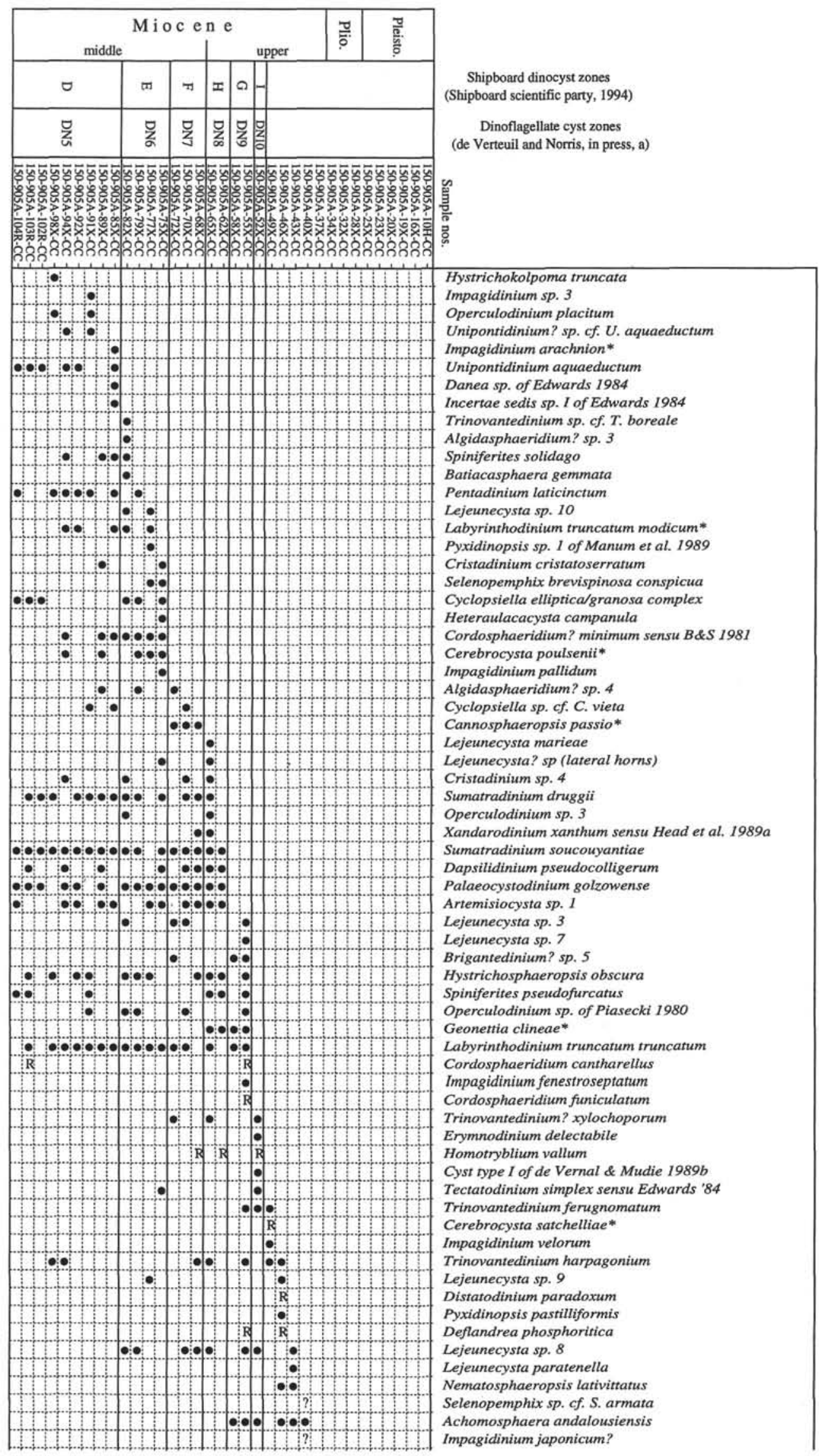


Table 5 (continued).

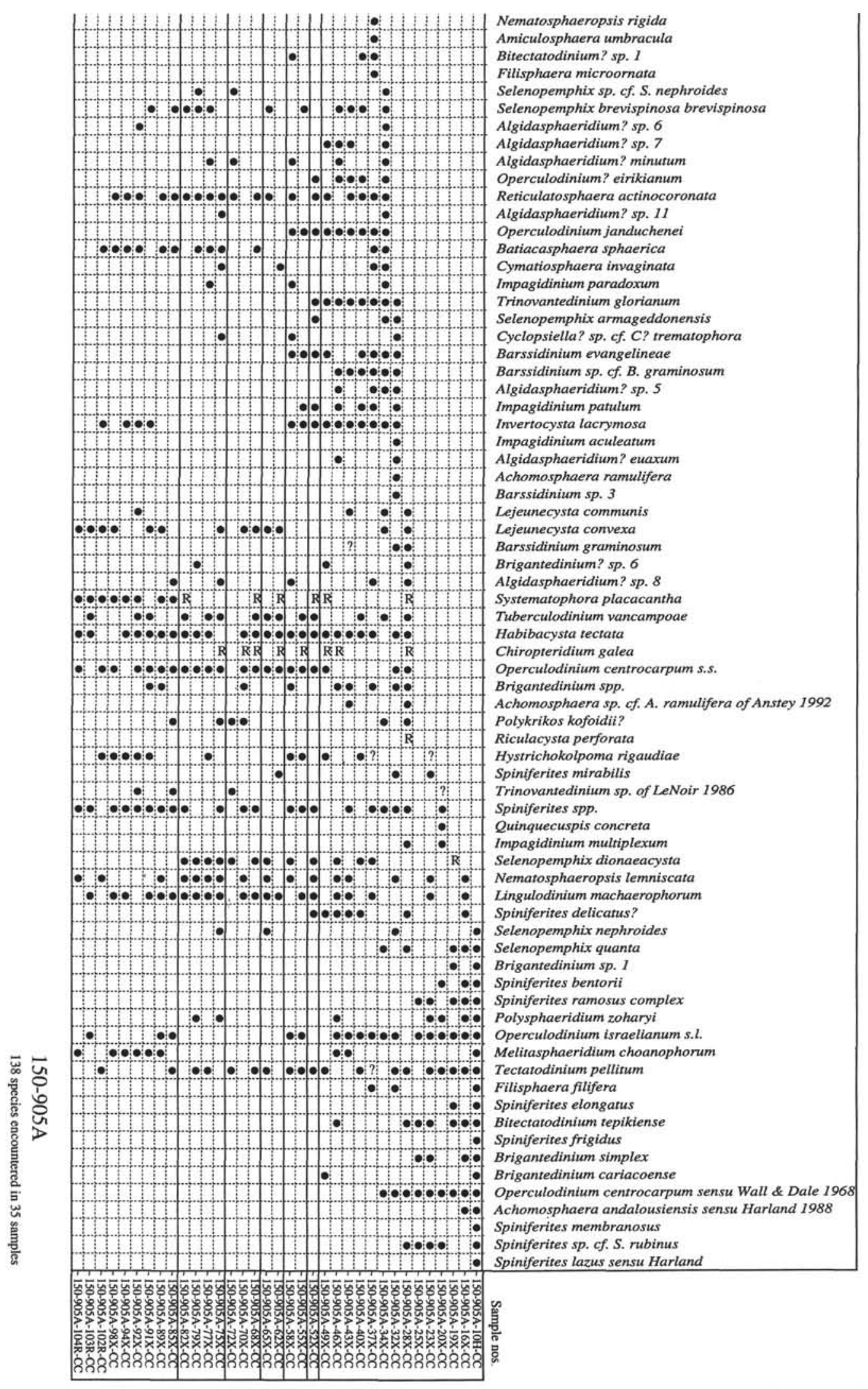

Notes: The depth (mbsf) for each sample is given in Shipboard Scientific Party (1994e, table 4). Solid dots indicate in situ occurrences; the symbol "R" indicates occurrences that are considered to have resulted from reworking; the symbol "?" in the chart indicates tentative identification of the taxon in a particular sample. Taxon names followed by an asterisk ${ }^{*}$ ) are from de Verteuil and Norris (in press, b, c); published taxon names followed by a question mark (?) indicate that assignment to the taxon is tentative. 
Table 6. Stratigraphic distribution of dinocyst taxa from Hole 906A, in ascending highest occurrence.

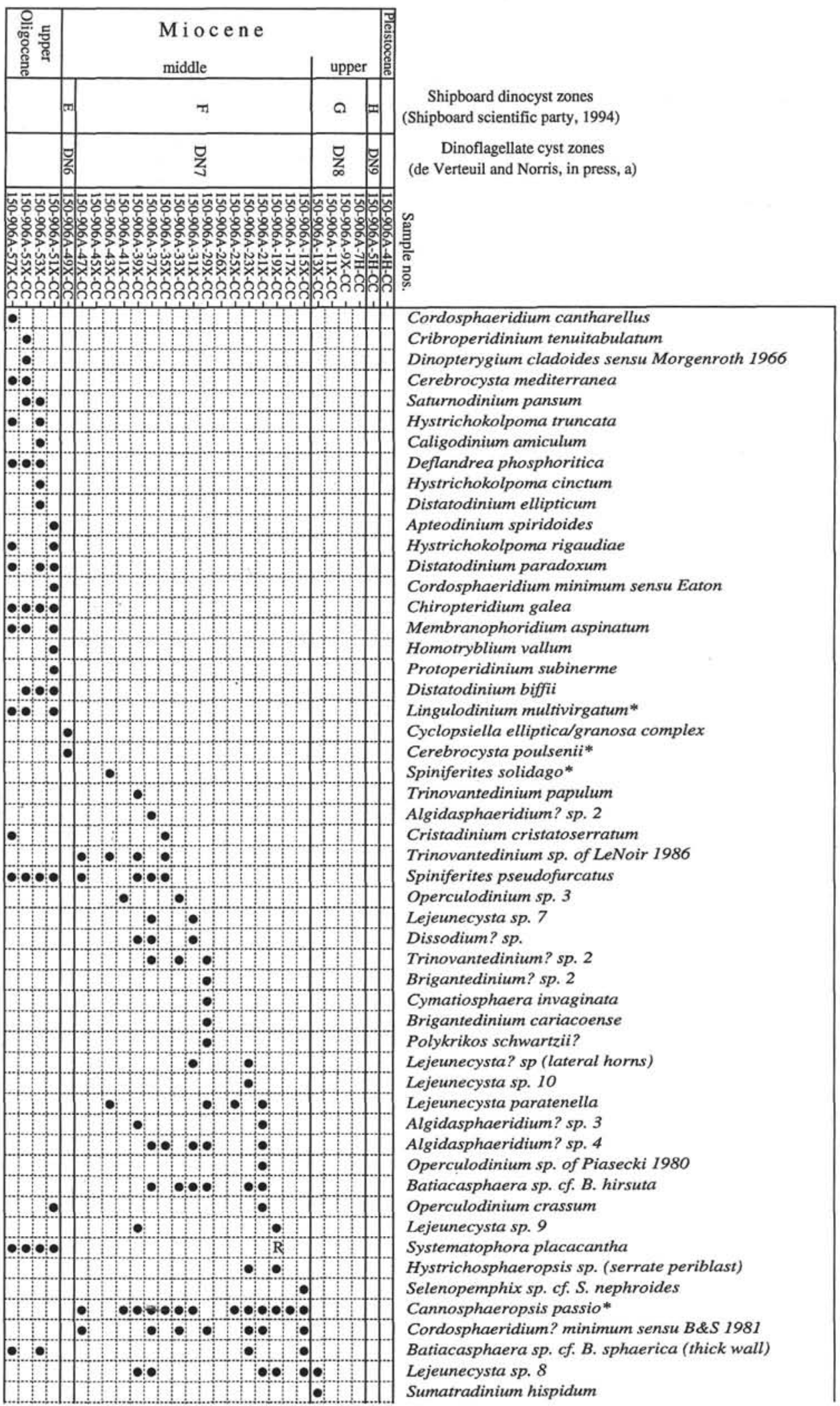


Table 6 (continued).

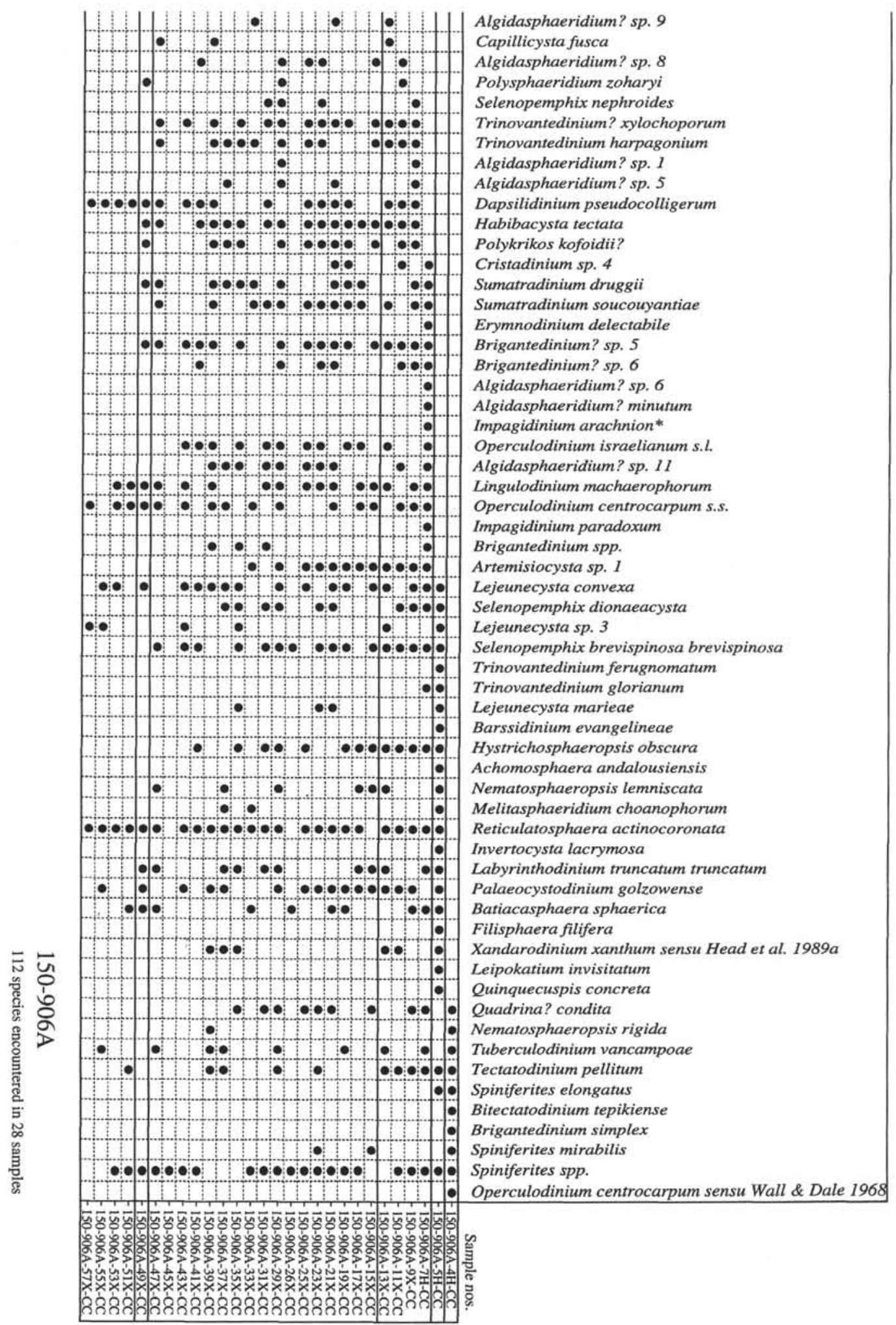

Notes: The depth (mbsf) for each sample is given in Shipboard Scientific Party (1994f, table 4). Solid dots indicate in situ occurrences; the symbol " $\mathrm{R}$ " indicates occurrences that are considered to have resulted from reworking. Taxon names followed by an asterisk (*) are from de Verteuil and Norris (in press, b, c); published taxon names followed by a question mark (?) indicate that assignment to the taxon is tentative. 


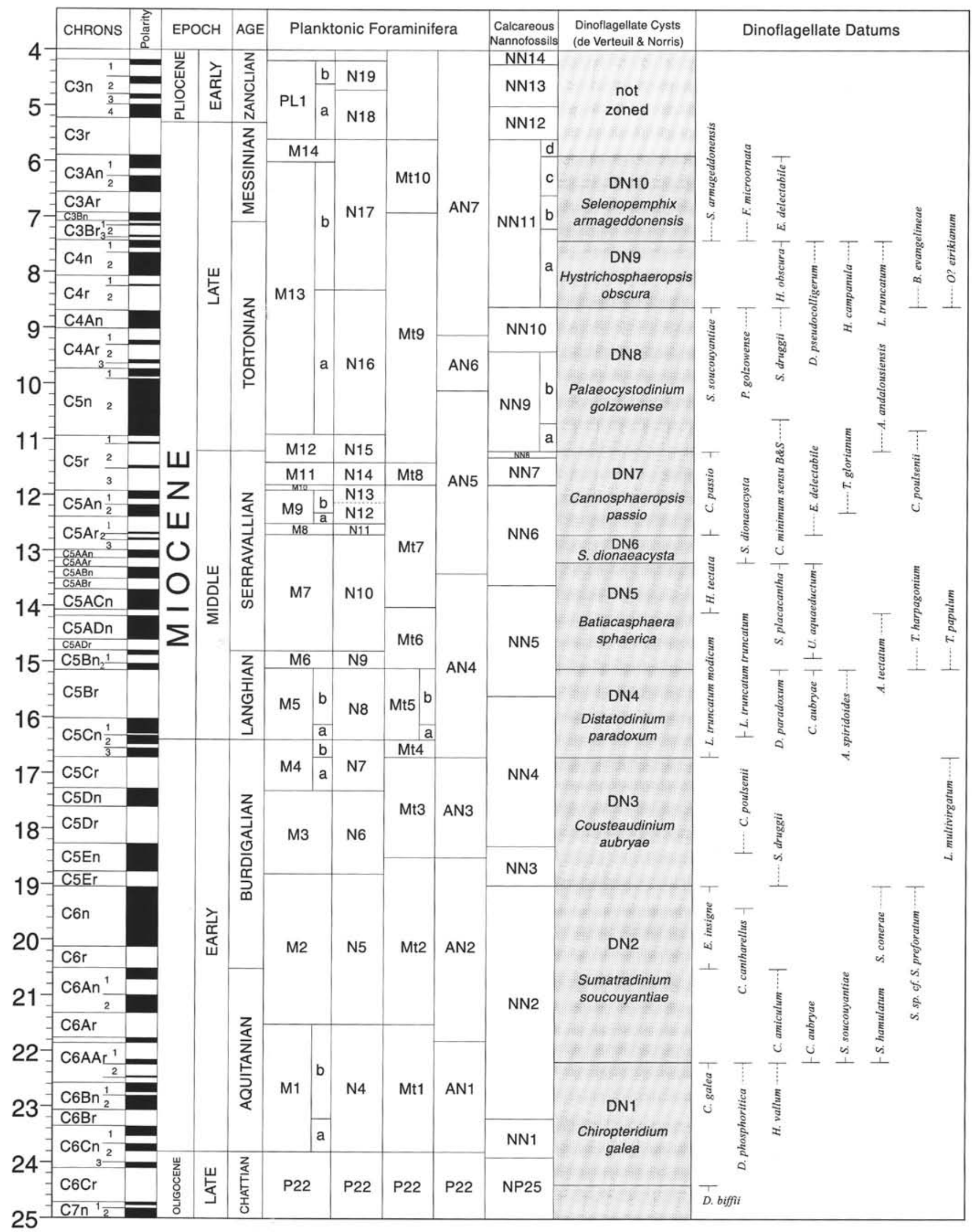

Figure 2. Summary of the temporal duration of DN Zones 1 through 10, together with dinocyst datums for the western North Atlantic, calibrated to the timescale of Berggren et al. (1995). Dashed lines indicate uncertainty in some datum calibrations. 